\title{
Kaitan Kuasa Pertambangan dengan Hak-hak atas Tanah dalam Undang-Undang Poksok Agrạia
}

\author{
Mukmin Zakie
}

\begin{abstract}
This paper tries to emerge the phenomena of Mining Authority and Land Right in the Basic Principle of Agrarian Law. Argumentatively, the Act of Mining No. 11, 1967 does not show any relationship to the considerance of the Principal Act of Agrarian (UUPA). Its existence (UUPA) is not explicitly stated in the Body Frame, and is mentioned unclearly on Article 2 letter $b$ of the Basic Principle of Agrarian Law (UUPA). The Article states that land rights are rights on the land area located in certain part of the earth based on the Indonesian Law. This perception seems clear when the Indonesian Law is indefinitely elaborated. However, if it is traced, there is a close relationship between The Basic Principal of Mining $\bar{A} c t$ and the Basic Principle of Agrarian Law.
\end{abstract}

\section{Pendahuluan}

Peraturan pertambangan di Indonesia sudah ada sejak zaman kolonial Belanda yang diatur dalam Indonesische Mijnwet (Stbl. 1899 No. 214). Di dalam Indonesische Mijnwet tersebut diatur pemberian wewenang kepada orang atau badan hukum untuk melakukan kegiatan pertambangan dalam bentuk hak konsesi.

Konsesi adalah suatu hak yang diberikan kepada orang (Belanda atau Hindia Belanda) atau badan hukum (yang ada di Belanda maupun di Hindia Belanda) untuk mengusahakan lahan baik untuk perkebunan, peternakan, dan pertambangan selama 75 tahun dengan membayar iuran kepada pemerintah Hindia Belanda. Konsesi ini memberikan hak yang amat kuat kepada. pemegangnya. Pemegang konsesi berlaku sebagai pemilik atas lahan atau tanah yang dikuasainya. Segala hasil yang didapat dari daerah konsesi tersebut menjadi hak milik pemegang konsesi. Konsesi pertambangan didaftarkan menurut overschrijving ordonantie (S.1834 No. 27), yang dapat dijadikan sebagai jaminan hutang dengan pembebanan hipotik.

Setelah indonesia merdeka, Indonesische Mijnwet ini dicabut dengan diundangkannya Undang-Undang Nomor 37 Prp. 1960. Pada mulanya undang-undang ini berupa peraturan pemerintah pengganti undang-undang (Perpu), yakni Perpu Nomor 37 Tahun 1960 yang kemudian disahkan oleh DPR menjadi undang-undang. 
Setelah diundangkannya UndangUndang Nomor 37 Prp. 1960 istilah konsesi diganti dengan Kuasa Pertambangan. Adapun pengertian Kuasa Pertambangan adalah wewenang yang diberikan oleh pemerintah dalam hal ini Menteri Pertambangan dan Energi kepada badan atau perorangan untuk melaksanakan usaha pertambangan.

Pemberian Kuasa Pertambangan kepada pemegang Kuasa Pertambangan tidak memberikan hak pemilikan pertambangan kepadanya. Pemegang Kuasa Pertambangan tidak dapat dikatakan melakukan pekerjaan pertambangan sebagai pemilik wilayah pertambangan yang bersangkutan. la melakukan usaha pertambangan sebagai pihak yang diberi kuasa atau tugas oleh negara dan bangsa. Oleh karena ia memberikan jasa kepada bangsa dan negara dengan melakukan usaha pertambangan itu maka kepadanya diberikan penggantian jasa. Penggantian jasa ini yang menjadi milik pemegang Kuasa Pertambangan.'

Oleh karena bahan galian tersebut merupakan hak bangsa Indonesia dan kekayaan nasional, maka menurut penjelasan Undang-Undang Pokok Pertambangan, negara menguasai dengan sepenuhnya sebagaimana dengan tegas dinyatakan dalam UUPA dan Undang-Undang -Pokok Pertambangan (UUPP), bukan dalam arti pemilikan.

Undang-Undang Nomor 37 Prp. 1960 hanya bertahan selama kurang lebih 7 tahun, karena pada tahun 1967 telah dikeluarkan peraturan perundang-undangan yang mengatur masalah pertambangan yaitu Undang-Undang Nomor 11 tahun 1967 yang disebut Undang-Undang Pokok Pertambangan. Setelah diundangkannya Undang-Undang Nomor 11 tahun 1967 tersebut, dengan sendirinya undang-undang sebelumnya tidak berlaku lagi. Salah satu alasan pencabutan Undang-Undang Nomor 37 Prp. 1960 tersebut karena sudah tidak sesuai lagi dengan kebutuhan negara dan masyarakat dalam melaksanakan pertambangan. Namun demikian, prinsip-prinsip dasar pertambangan yang ada dalam Undang-Undang Nomor 11 tahun 1967 tetap memakai apa yang diatur dalam undang-undang sebelumnya dengan penyempurnaan dan perluasan pada beberapa materi.

Di dalam Undang-Undang Nomor 11 Tahun 1967 bahan galian pertambangan dibedakan atas tiga golongan, yakni Golongan A (strategis), Golongan B (vital) dan Golongan $C$ (golongan yang tidak termasuk strategis dan vital). Salah satu dasar dari penggolongan bahan galian tersebut adalah pemberian kesempatan pengembangan penguasaan dan ini juga berkaitan dengan tata cara perizinannya. Untuk Golongan Adan Golongan $B$, izin pengusahaannya diperoleh dari Menteri Pertambangan dan Energi (Mentamben) dan izin ini disebut Kuasa Pertambangan. Sedangkan untuk Golongan $C$, izin untuk pengusahaannya diberikan oleh Gubernur Kepala Daerah Tingkat I. Izin ini disebut Surat Kuasa Pertambangan Daerah (SIPD). Pelimpahan wewenang pemberian izin usaha pertambangan Golongan $C$ kepada gubernur

'Syamsul Bahri Dt. Saripado. 1987. Hukum Agraria Indonesia Dulu dan Kini. Tanpa Penerbit. HIm.199 
yang berupa SIPD ini diatur di dalam Peraturan Pemerintah Nomor 37 Tahun 1986 tentang Penyerahan Sebagian Urusan Pemerintah dibidang Pertambangan Kepada Pemerintah Daerah Tingkat 1.

Usaha pertambangan mutlak memerlukan tanah, akan tetapi pemberian Kuasa Pertambangan atau Surat Izin Pertambangan Daerah tidak meliputi hak atas tanah di permukaan bumi, dengan demikian terjadi pemisahan antara hak atas tanah permukaan bumi dengan hak unituk menggali barang tambang yang ada di dalam bumi. Padahal hakekatnya keduanya saling bersentuhan malahan satu, hanya dibedakan dalam dua pengertian dan isinya; satu pada 'lapisan atas' yang lainnya pada 'lapisan bawah' di bumi yang säma, ${ }^{2}$ Dengan demikian seolah-olah ada perbedaan antara bumi yang ada di atas dan yang ada dalam tubuh bumi. UndangUndang Pokok Agraria telah memberikan suatu pengertian yang luas tentang apa yang dimaksud dengan bumi, yakni bukan hanya yang ada di atas bumi melainkan juga apa yang ditanam di permukaan bumi dan apa yang ada di tubuh bumi. ${ }^{3}$ Demikian juga tentang tata cara pengambilan kekayaan baik yang ada di bumi, air dan ruang angkasa akan diatur oleh UUPA (Pasal 8).

Memang diakui bahwa UUPA baru mengatur masalah status hak untuk permukaan bumi yakni yang termuat dalam Pasal 16 tentang Hak-hak Atas tanah. Namun demikian, kalau disimak bunyi Pasal 8 UUPA di atas, UUPA bertanggung jawab untuk membuat peraturan (baik peraturan pemerintah maupun undang-undang) tentang tata cara pengambilan kekayaan yang ada di bumi, air, dan ruang angkasa. Konsekuensinya segala peraturan yang menyangkut keagrarian dalam arti luas tersebut harus merujuk pada UUPA sebagai satu kesatuan sistem yang utuh untuk menghindari konflik

Undang-undang Pokok Pertambangan baik di dalam konsideran maupun batang tubuhnya tidak mencantumkan UUPA sebagai pedoman pengaturan hak atas tanah, akan tetapi hanya disinggung masalah hak atas tanah menurut hukum Indonesia. Padahal pengertian bumi dalam UUPA mempunyai arti yang luas yakni bukan hanya bumi dalam pengertian tanah permukaan bumi tetapi juga meliputi apa yang ditanam pada permukaan bumi serta yang terkandung di dalam tubuh bumi (pertambangan). Tata cara pengambilan kekayaan alam tersebut diatur dalam Pasal 8 UUPA yang menegaskan bahwa UUPA kelak akan mengatur tentang pengambilan kekayaan alam yang terkandung di dalam bumi, air, dan ruang angkasa.

\section{Undang-Undang Nomor 11 Tahun 1967}

Undang-Undang Nomor 11 tahun 1967 tentang Ketentuan Pokok-pokok Pertambangan yang berdasarkan ketentuan Pasal 37 disebut juga dengan Undang-Undang Pokok Pertambangan (UUPP) merupakan realisasi Pasal 33 ayat (3) Undang-Undang Dasar 1945. Ada tiga masalah yang diatur dalam Undang-

2John Salindeho. 1987. Masalah Tanah dalam Pembangunan. Cetakan 1. Jakarta: Sinar Grafika.HIm. 215.

${ }^{3}$ A.P. Parlindungan. 1991. Komentar Atas Undang-Undang Pökok Agraria. Cetakan VI. Bandung: Mandar Maju. HIm. 36. 
Undang tersebut yaitu:

1. Penguasaan dan Penggolongan bahan galian;

2. Pengusahaan pertambangan; dan

3. Pengawasan pertambangan

Di samping itu dengan lahirnya UndangUndang Nomor 11 tahun 1967 ini ada beberapa hal yang berkenaan dengan tanah, hal tersebut ialah: ${ }^{4}$

1. Suatu penjebolan (in breuk) terhadap hak tanah dengan melahirkan kewajiban memperbolehkan pemegang kuasa pertambangan bekerja di atas tanah orang lain;

2. Hak khusus Menteri Pertambangan atas penentuan ganti kerugian atas tanah oleh pemegang kuasa pertambangan di atas; dan

3. Persoalan Pajak Bumi dan Bangunan (PBB) versus luran.

Pengaturan mengenai hak atas tanah adalah khusus lain daripada pengaturan umum agraria (UUPA) beserta peraturan pelaksanaannya. $^{5}$

Pembentukan UUPP, dimaksudkan dan ditujukan untuk mempercepat terlaksananya pembangunan ekonomi nasional dalam menuju masyarakat Indonesia yang adil dan makmur materiil dan spirituil berdasarkan Pancasila, oleh karena itu perlulah dikerahkan semua dana dan daya untuk menggalakkan dan membuka segenap kekuatan ekonomi potensial di bidang perkembangan menjadi kekuatan ekonomi riil. ${ }^{6}$

\section{Hak Menguasai dari Negara}

Di dalam Pasal 33 ayat (3) UndangUndang Dasar 1945 disebutkan bahwa bumi, air, dan kekayaan alam yang terkandung di dalamnya dikuasai oleh negara dan dipergunakan sebesar-besar kemakmuran rakyat". Kata-kata dikuasai oleh negara pada ayat (3) tidak mencerminkan pengertian dan makna yang jelas dan tegas, sehingga mengundang banyak penafsiran yang berimplikasi kepada implementasinya. Perbedaan implementasi ini baik dalam peraturan perundang-undangan maupun pelaksanaannya oleh departemen/ instansi pemerintah terkait. Akibatnya terjadi benturan kepentingan dan wewenang dalam penggunaan dan pemanfaatan sumber daya alam Indonesia.?

Di dalam Pasal 2 ayat (2) UUPA telah diberikan pengertian dan batasan secara otentik mengenai Hak Menguasai Negara (HMN) ini. Negara sebagai personifikasi seluruh rakyat diberikan wewenang untuk mengatur sehingga membuat peraturan, kemudian menyelenggarakan artinya melaksanakan (execution), atas penggunaan/ peruntukan (use), persediaan (reservation), dan pemeliharaannya (maintenance) dari bumi, air, ruang angkasa dan kekayaan alam

${ }^{4}$ Sumantoro. 1986. Hukum Ekonomi. Jakarta: UI Press. HIm. 75.

5/bid.

${ }^{8}$ John Salindeho. Op Cit. HIm. 214

${ }^{7}$ Abrar. 1999. "Sepercik Pemikiran Mengenai Hak Menguasai Negara atas Pertambangan di Indonesia". Jumal Hukum dan Keadilan. Vol 2. No.1. 
yang terkandung di dalamnya. ${ }^{8}$ Sedangkan menurut Boedi Harsono ${ }^{9}$ kewenangan Negara yang tersebut pada Pasal 2 itu meliputi baik bidang legislatif meliputi pengertian mengatur dan menyelenggarakan, bidang kekuasaan eksekutif dalam pengertian menyelenggarakan dan menentukan dan bidang yudikatif dalam hal menyelesaikan sengketa-sengketa tanah baik antara rakyat maupun antara rakyat dan pemerintah.

Sejalan dengan hal tersebut Bagir Manan mengemukakan apabila pengertian dikuasai oleh negara tidak hanya menyangkut bumi, air, dan ruang angkasa serta kekayaan alam yang terkandung di dalamnya, unsur utama penguasaan negara adalah untuk mengatur dan mengurus (regelen en bestuuren). ${ }^{10}$

\section{Kuasa Pertambangan}

Salah satu objek HMN adaiah kekayaan yang terkandung di dalam tubuh bumi yang berupa mineral-mineral atau bahan-bahan galian lainnya yang disebut bahan galian tambang. Hak menguasai oleh negara terhadap bahan tambang tersebut dapat disimak dalam Pasal 1 Undang-Undang Nomor No.11 Tahun 1967 yang berbunyi:

Segala bahan galian yang terdapat dalam wilayah hukum pertambangan Indonesia yang merupakan endapan-endapan alam sebagai karunia Tuhan Yang Maha Esa, adalah kekayaan nasional bangsa Indonesia dan oleh karenanya dikuasai dan dipergunakan oleh negara untuk sebesarbesar kemakmuran rakyat.

Pasal 1 di atas adalah sebagai pelaksana dari hak menguasai negara yang tercantum dalam Pasal 33 ayat (3) Undang-Undang Dasar 19451945 di mana segala kekayaan alam yang terkandung baik di bumi, air dan ruang angkasa dikuasai sepenuhnya oleh negara. Negara dapat memberikan sebagian hak tersebut kepada perorangan maupun badan hukum untuk mengusahakan penggalian kekayaan alam tersebut.

Demikian halnya dengan pertambangan, negara memberikan wewenang kepada badan atau perorangan untuk melakukan usaha pertambangan. Wewenang untuk mengusahakan pertambangan ini disebut kuasa pertambangan (mining authorization).

Pemberian kuasa pertambangan kepada pemegang kuasa pertambangan tidak dapat dikatakan melakukan pekerjaan-pekerjaan pertambangan sebagai pemilik wilayah pertambangan yang bersangkutan. la melakukan usaha pertambangan sebagai pihak yang diberi kuasa (otoritas) atau tugas oleh negara dan bangsa. Oleh karena ia memberikan jasa kepada bangsa dan negara dengan melakukan usaha pertambangan tersebut, maka kepadanya diberikan penggantian jasa. Penggantian jasa ini yang menjadi milik pemegang Kuasa Pertambangan.

${ }^{8}$ A.P. Parlindungan. Op Cit. Him. 39.

'Boedi Harsono. 1997. Hukum Agraria Indonesia: Sejarah Pembentukan UUPA Isi dan Pelaksanaannya. jlij 1. Edisi Revisi. HIm. 239-241.

${ }^{10}$ Bagir Manan. 1995. "Aspek Hukum Penguasaan Daerah Atas Bahan Galian". Makalah disampaikan dalam Seminar Nasional Pertambangan. Diselenggarakan oleh Lembaga Penelitian Unpad. Bandung.Hlm.2. 


\section{Hak dan Kewajiban Pemegang Kuasa Pertambangan}

Hak-hak dan kewajiban-kewajiban pemegang kuasa pertambangan diatur dalam Peraturan Pemerintah Nomor 32 Tahun 1969 yang dicantumkan dalam Surat Keputusan Pemberiannya. Hak yang diberikan antara lain hak untuk melakukan segala usaha sesuai dengan wewenang yang diberikan dalam Kuasa Pertambangannya berdasarkan Pasal 26 ayat (1) dan Pasal 27 ayat (2). Hak untuk mendapat prioritas pertama guna memperoleh kuasa pertambangan tahap berikutnya berdasarkan Pasal-pasal 25, 26, 2728 dan 29. Hak untuk memiliki bahan galian yang dihasilkan, berdasarkan Pasal 26 ayat (2) dan 27 ayat (3) dan hak untuk pelaksanaan usaha pertambangan berdasarkan Pasal 37 .

Di samping itu kewajiban-kewajiban yang harus dipenuhi oleh pemegang Kuasa Pertambangan antara lain disebut kewajiban untuk memenuhi syarat-syarat yang ditetapkan bagi Kuasa Pertambangan. Kewajibankewajiban tersebut untuk melakukan perintahperintah dan atau peturjuk-petunjuk yang telah ditetapkan oleh pihak berwenang. Pemegang Kuasa Pertambangan diwajibkan untuk telah memulai usaha pertambangannya dalam waktu yang telah ditentukan.

Sebelum memulai usahanya maka pemegang Kuasa Pertambangan eksploitasi wajib melaporkan rencana usaha penggaliannya serta target produksinya kepada Menteri. Secara berkala pemegang Kuasa Pertambangan wajib menyampaikan laporan mengenai hasil usaha pertambangan yang diselenggarakannya. Semuanya bertujuan agar Kuasa Pertambangan yang diberikan itu benar-benar dilaksanakan sebagaimana mestinya hingga mencapai hasil yang diharapkan.

Berhasilnya usaha pertambangan yang bersangkutan bukan hanya penting bagi pemegang Kuasa Pertambangan sendiri, melainkan juga menyangkut kepentingan bangsa dan negara. Oleh karena itu, selain dapat dijadikan alasan untuk membatalkan kuasa pertambangan yang bersangkutan, kelalaian daiam memenuhi dan atau dalam menjalankan kewajiban itu dapat mengakibatkan juga dijatuhkan hukuman pidana kepada pemegang kuasa pertambangan.

Pemegang Kuasa Pertambangan juga wajib mengindahkan ketentuan-ketentuan yang menyangkut hubungannya dengan mereka yang mempunyai hak atas tanah.

Pemegang kuasa pertambangan wajib membayar kepada negara iuran tetap, iuran eksplorasi dan juga juran eksploitasi serta pembayaran-pembayaran lainnya yang berhubungan dengan kuasa pertambangan yang bersangkutan.

luran tetap (landrent) adalah iuran yang dibayarkan kepada Negara sebagai imbalan atas kesempatan yang diberikan kepada pemegang kuasa pertambangan untuk menyelenggarakan penyelidikan umum, eksplorasi atau eksploitasi pada suatu wilayah kuasa pertambangan yang tertentu. Besamya iuran-iuran tersebut ditetapkan oleh Menteri.

luran eksplorasi atau royalti adalah iuran produksi yang dibayarkan kepada negara dalam hal pemegang Kuasa Pertambangan eksplorasi mendapat hasil berupa bahan galian sewaktu menyelenggarakan usaha eksplorasi.

Pembayaran iuran tetap mempunyai arti yang penting bagi pemegang kuasa pertambangan karena bahan galian yang telah 
digali atau ditambang itu baru menjadi miliknya setelah pembayaran iuran tetap dan royalti dipenuhi.

\section{Macam-macam Kuasa Pertambangan}

\section{Kuasa Pertambangan Penyelidikan Umum}

Penyelidikan Umum adalah penyelidikan secara geologi umum atau geofisika di daratan, perairan, dan dari udara, segala sesuatu dengan maksud membuat peta geologi umum atau untuk menetapkan tanda-tanda adanya bahan galian pada umumnya.

Kuasa pertambangan penyelidikan umum diberikan selama-lamanya 1 tahun dan dapat diperpanjang selama satu tahun lagi, atas permintaan yang bersangkutan dan diajukan sebelum berakhimya jangka waktu yang telah ditetapkan.

Kepada orang atau badan hukum yang diberikan Kuasa Pertambangan Penyelidikan Umum diwajibkan membayar iuran tetap kepada negara. luran tetap adalah iuran yang dibayarkan kepada negara sebagai imbalan atas kesempatan untuk melakukan usaha pertambangan penyelidikan umum, iuran tetap ini dibayarkan pada awal tahun dan jumlahnya berdasarkan tiap hektar wilayah Kuasa Pertambangan.

\section{Kuasa Pertambangan Eksplorasi}

Kuasa Pertambangan Eksplorasi adalah wewenang yang diberikan untuk melakukan segala penyelidikan geologi pertambangan untuk menetapkan lebih teliti atau seksama adanya dan sifat letakan bahan galian. Kuasa Pertambangan eksplorasi diberikan selama- lamanya 3 tahun dan dapat diperpanjang 2 kali. Setiap kalinya satu tahun atas permintaan yang bersangkutan yang harus diajukan sebelum berakhirnya jangka waktu yang telah ditetapkan. Seperti halnya Kuasa Pertambangan penyelidikan umum, pada eksplorasi ini juga dipungut biaya atau iuran tetap yang dibayarkan pada awal tahun dan diperhitungkan berdasarkan luas Kuasa Pertambangan tersebut. Di samping membayar iuran tetap, juga diwajibkan membayar iuran eksplorasi yakni iuran produksi yang dibayarkan kepada negara dalam hal pemegang Kuasa Pertambangan eksplorasi memperoleh hasil bahan galian yang tergali atas kesempatan melakukan usaha pertambangan eksplorasi yang diberikan kepadanya.

\section{Kuasa Pertambangan Eksploitasi}

Kuasa Pertambangan Eksploitasi adalah wewenang yang diberikan kepada orang atau badan untuk melakukan usaha pertambangan dengan maksud untuk menghasilkan bahan galian dan memanfaatkannya. Kuasa Pertambangan Eksploitasi diberikan selamalamanya 30 tahun dan dapat diperpanjang 2 kali setiap kalinya 10 tahun.

Kepada pemegang Kuasa Pertambangan eksploitasi diwajibkan membayar iuran eksploitasi yakni iuran produksi yang dibayarkan kepada negara atas hasil produksi yang diperolehnya dari usaha pertambangan eksploitasi satu atau lebih bahan galian.

Di samping iuran untuk kegiatan eksploitasi tersebut juga dikenai iuran tetap yang tata cara pembayarannya sama seperti Kuasa Pertambangan penyelidikan umum dan Kuasa Pertambangan eksplorasi. 


\section{Kuasa Pertambangan Pengolahan dan Pemurnian}

Kuasa Pertambangan pengolahan dan pemurnian adalah wewenang yang diberikan kepada pemegang Kuasa Pertambangan atas pengerjaan untuk mempertinggi mutu bahan galian serta untuk memanfaatkan dan memperoleh unsur-unsur yang terdapat pada bahan galian itu.

Kuasa Pertambangan pengolahan dan pemurnian ini diberikan selama-lamanya 30 tahun dan dapat diperpanjang setiap kalinya selama 10 tahun atas permintaan yang bersangkutan yang harus diajukan sebelum berakhimya jangka waktu yang telah ditetapkan.

\section{Kuasa Pertambangan Pengangkutan dan Penjualan}

Kuasa Pertambangan pengangkutan dan penjualan adalah wewenang untuk melakukan usaha pertambangan pengangkutan dan penjualan.

Pengangkutan adalah segala usaha pemindahan bahan galian dan hasil pengolahan dan pemurnian bahan galian dari daerah eksplorasi atau tempat pengolahan atau pemurnian. Sedangkan pengertian penjualan adalah segala usaha penjualan bahan galian dan hasil pengolahan atau pemumian bahan galian.

Kuasa Pertambangan pengangkutan dan penjualan ini diberikan selama-lamanya 10 tahun dan dapat diperpanjang setiap kalinya selama-lamanya 5 tahun.

\section{Hubungan Kuasa Pertambangan dengan Hak-hak atas Tanah}

Untuk mempergunakan tanah yang terdapat dalam wilayah pertambangan itu, pemegang kuasa pertambangan perlu mempunyai hak atas tanah yang sesuai dengan tujuan penggunaannya. Di dalam Undang-Undang Nomor 11 Tahun 1967 (Undang-Undang Pokok Pertambangan) dijumpai ketentuan-ketentuan mengenai hubungan antara pemegang kuasa pertambangan dan mereka yang mempunyai hak atas tanah dalam wilayah pemegang kuasa pertambangan yang bersangkutan.

Pada asasnya para pemegang hak atas tanah wajib untuk memperbolehkan pemegang kuasa pertambangan melakukan pekerjaan di atas tanah tanah yang bersangkutan. Jika dalam hal itu pemegang hak atas tanah menderita kerugian, maka pemegang kuasa pertambangan wajib memberikan pengganti kerugian kepada pemegang hak tersebut.

Pemegang Kuasa Pertambangan diwajibkan mengganti kerugian akibat dari usahanya pada segala sesuatu yang berada di atas tanah kepada yang berhak atas tanah di dalam lingkungan daerah kuasa pertambangan maupun di luarnya, tanpa memandang apakah perbuatan itu dilakukan dengan atau tidak dengan sengaja, juga jika hal tersebut tidak diketahui lebih dahulu.

Kerugian yang disebabkan oleh kuasa usaha dari dua pemegang kuasa pertambangan atau lebih, dibebankan kepada mereka bersama. Sebaliknya mereka yang berhak atas tanah diwajibkan memperbolehkan pemegang kuasa pertambangan atas tanah yang bersangkutan dengan dasar musyawarah mufakat, jika kepadanya sebelum pekerjaan dimulai dan memperlihatkan surat kuasa pertambangan atau salinannya yang sah, diberitahukan tentang maksud dan tempat pekerjaan itu akan dilakukan. Juga jika pemegang hak atas tanah 
itu telah diberi ganti kerugian atau jaminan ganti kerugian terlebih dahulu.

Jumlah ganti kerugian itu ditentukan bersama oleh pemegang kuasa pertambangan dengan yang berhak atas tanah berdasarkan musyawarah, yaitu berupa pengganti satu kali atau selama hak atas tanahnya tidak dapat dipergunakan. Jika tidak dapat dicapai kata sepakat, maka penentuannya diserahkan kepada Menteri Pertambangan dan Energi.

Apabila setelah dikeluarkannya ketetapan menteri dalam hal ganti rugi ini salah satu tetap tidak menerima, maka penetapan ganti kerugian itu diserahkan kepada pengadilan negeri di daerah yang bersangkutan. Ganti kerugian segala biaya yang berhubungan dengan usaha pertambangan itu dibebankan kepada pemegang kuasa pertambangan yang bersangkutan. Pengaturan tersebut di atas diatur dalam Pasal 25 sampai dengan Pasal 27 Undang-Undang Pokok Pertambangan.

Kuasa pertambangan eksplorasi dan kuasa pertambangan eksploitasi dapat dibatalkan atas permintaan pemilik tanah atau pihak ketiga. Hal ini apabila ternyata pekerjaan eksplorasi atau eksploitasi telah dimulai sebelum dibayar ganti kerugian atau jaminan ganti kerugian yang dimaksudkan.

Sejak kemerdekaan, perselisihan mengenai tanah antara rakyat dan pemerintah secara umun telah terjadi karena pandangan yang berbeda mengenai konsep hak atas tanah. Perbedaan pandangan tersebut bukanlah hal yang baru karena telah tejadi sejak masa dahulu. Frekuensi perselisihan telah meningkat sehubungan dengan pertumbuhan penduduk sementara tanah relatif tetap terbatas luasnya. ${ }^{11}$

Menurut A.P. Parlindungan, ${ }^{12}$ UUPA semula diniatkan untuk menjadi basic law dalam pengaturan keagrariaan sebagai implementasi Pasal 33 ayat (3) UndangUndang Dasar 1945. Namun kenyataan yang dihadapi semenjak tahun 1967 telah terjadi perceraian dengan UUPA karena adanya peraturan perundang-undangan bersifat sektoral. ${ }^{13}$ Salah satu peraturan perundangundangan yang mengatur bidang sektoral adalah Undang-Undang Pokok Pertambangan.

Undang-Undang Nomor 11 Tahun 1967 dikeluarkan dengan orientasi pada pembangunan ekonomi. Hal ini dapat dilihat dari konsideran dan sejarah kelahirannya.

Setelah kudeta PKI tanggal 30 September 1965 gagal, bangkitlah kekuatan baru yang bertekad untuk menjalankan Undang-Undang Dasar 1945 dan Pancasila secara murni dan konsekuen. Kekuatan baru ini menyebut dirinya Orde Baru.

Pada awal kehadirannya Orde Baru dihadapkan kepada dua masalah besar yaitu chaos politik dan lumpuhnya ekonomi negara dengan laju inflasi yang hampir-hampir fantastik. Pada masa Orde Lama, masalah

"Erman Rajagukguk. 1995. Hukum Agraria, Pola Penguasaan Tanah dan Kebutuhan Hidup. Jakarta: Chandra Pratama. HIm. 35.

${ }^{12}$ A.P. Parlindungan. 1993. "Peninjauan Beberapa Produk Hukum yang Berkaitan dengan UUPA." Pidato Purna Bakti selaku Guru Besar Tetap USU. HIm. 4.

${ }^{13}$ A.P. Parlindungan. 1993. Komentar Atas Undang-Undang Penataan Ruang (UU No.24 Tahun 1992). Cetakan I. Bandung: Mandar Maju. HIm. 2. 
ekonomi ini tidak mendapat perhatian serius jika tidak dikatakan diabaikan sama sekali. Pemerintah lebih suka menjaga keseimbangan politik daripada terburu-buru membuat keputusan dalam bidang ekonomi. ${ }^{14}$ Pilihan sikap orde lama yang demikian oleh Mackie dikatakan sebagai sikap menjaga perimbangan politik dengan mengorbankan keseimbangan ekonomi. ${ }^{15}$

Pada waktu itu difisit anggaran negara mencapai angka $50 \%$. Keadaan ini digambarkan oleh Anne Both dan Peter MacCawley sebagai berikut:

Pertengahan dasawarsa 60 -an adalah masa suram bagi perekonomian Indonesia. Tingkat produksi dan investasi diberbagai sektor utama menunjukkan kemunduran semenjak tahun 1950. Pendapatan riil perkapita dalam tahun 1966 sangat mungkin lebih rendah daripada dalam tahun 1938. Sektor industri yang menyumbangkan hanya sekitar 10 dari GDP dihadapkan pada masalah pengangguran dalam kapasitas yang serius. Di awal dasawarsa tersebut defisit anggaran belanja negara mencapai 50.5 dari keperluan total negara, penerimaan ekspor sangat menurun, dan selama tahun 1960-1966 hiperinflasi melanda negara ini dengan lumpuhnya perekonomian. ${ }^{16}$
Bertolak dari kelumpuhan ekonomi yang seperti itulah orde baru memulai pejalanannya pada tahun 1966, dan berdasarkan fakta itu rezim ini memilih pembangunan ekonomi sebagai sasaran utama programnya.

Strategi pembangunan ekonomi sebagai sasaran utama orde baru berorientasi pada pertumbuhan yakni strategi, yang antara lain, menekankan bahwa pembangunan akan bermula dari pertumbuhan ekonomi yang disuntik pada teknologi dan modal asing. ${ }^{17}$

Dalam situasi seperti inilah maka produk hukum yang dikeluarkan oleh rezim orde baru berorientasi pada pembangunan ekonomi, hal ini sangat berbeda dengan masa orde lama di mana produk hukumnya berorientasi pada stabilitas politik.

Sebagai langkah awal untuk membenahi ekonomi negara yang porak poranda, maka pemerintah memberikan kesempatan kepada modal asing untuk menanamkan investasinya ke Indonesia dengan diundangkannya Undang-Undang Nomor 1 Tahun 1967 tentang Penanaman Modal Asing. Di samping mengharapkan masuknya modal asing tak lupa potensi dalam negeri pun harus digali, salah satu sektor yang harus digali adalah pertambangan sehingga keluarlah UndangUndang Nomor 11 Tahun 1967.

Meskipun Undang-Undang Nomor 11 Tahun 1967 ini mencabut Undang-Undang

1Moh. Mahfud MD. 1993. "Perkembangan Politik Hukum: Studi Tentang Pengaruh Konfigurasi Politik Terhadap Produk Hukum di Indonesia." Disertasi S3. UGM. HIm. 370.

15Jamie Mackie. 1967. "Problems of Indonesian Inflation." Ithaca: Cornell Modern Indonesian Project. HIm. 10 dalam ibid. Hlm. 370.

${ }^{16}$ Arne Both dan Peter MacCawley. "Perekonomian Indonesia Sejak Pertengahan Tahun EmpatPuluhan". Dalam Anne Both dan Peter MacCawley. 1985. Ekonomi Orde Baru, Jakarta: LP3ES. Hlm. 1.

${ }^{17}$ Moh. Mahfud MD. Op Cit. HIm. 372. 
Nomor 37 Prp. Tahun 1960, namun dari segi materi pengaturannya pada umumnya sama, dengan perubahan-perubahan prinsip pengaturan kebijaksanaan antara lain:

a. sifat perusahaan pertambangan yang semula pada dasarnya harus dilakukan oleh negara, perusahaan negara atau daerah atau usaha-usaha lainnya, dirubah menjadi harus dapat diusahakan oleh semua fihak yang berminat dan sanggup dengan tetap memperhatikan segi keamanan negara dan tetap berdasarkan asas-asas kekeluargaan; dan

b. Peranan pemerintah daerah lebih diperkuat.

Undang-Undang Nomor 11 Tahun 1967 . juga bersumber langsung pada Pasal 33 Undang-Undang Dasar 1945. Di dalam konsiderannya tidak menyinggung UUPA. Demikian juga dalam batang tubuh tidak secara tegas menyinggung Undang-Undang Pokok Agraria, yang ada hanya pada Pasal 2 istilah-istilah pada huruf $b$ yang menyatakan bahwa hak tanah adalah hak atas sebidang tanah pada permukaan bumi menurut hukum. Indonesia. Tidak dijelaskan hukum Indonesia yang mana.

Timbul pertanyaan mendasar; Apakah lembaga Legislatif (DPR) pada saat pembahasan Rancangan UUPP ini lupa dengan UUPA ? Apakah mereka (anggota DPR) tidak membaca pengertian bumi yang diatur dalam UUPA? Terlebih lagi bila disimak bunyi Pasal 8 UUPA yakni atas dasar hak menguasai dari negara sebagaimana yang dimaksud dalam Pasal 2 diatur pengambilan kekayaan alam yang terkandung dalam bumi, air dan ruang angkasa.
Untuk menjawab pertanyaan di atas perlu dilakukan analisis mengapa tidak dicantumkan Undang-Undang Nomor 5 Tahun 1960 (UUPA) atas produk hukum yang dikeluarkan pada tahun 1967 khususnya Undang-Undang Nomor 11 Tahun 1967 (UUPP), meskipun jelas berkaitan dengan pengertian bumi dalam UUPA.

Pertama, pada waktu merumuskan Undang-Undang Nomor 11 tahun 1967. suasana pemerintahan masih dihinggapi trauma nasional akibat $\mathrm{G} 30 \mathrm{~S}$. PKI sehingga apapun yang berbau komunis harus ditinggalkan pada masa Orde Baru. Demikian pula UUPA ada anggapan - meskipun kelinbahwa UUPA adalah projek PKI, dengan anggapan seperti itu menjadikan pelaksanaan UUPA menjadi macet, bahkan cenderung dilupakan. Anggapan ini diperkuat dari sisi kelahiran UUPA di mana pada masa itu PKI adalah partai besar dan gerakannya telah menyusup ke segenap lapisan masyarakat sehingga tidak menutup kemungkinan UUPA pun sebagai produk dan alat propaganda PKI, terutama dengan konsep landreform-nya. Apalagi kalau diteliti secara cermat tidak ada satupun perkataan Pancasila dalam UUPA tersebut, meskipun di sana-sini dapat dijumpai beberapa perumusan tentang hal tersebut, sehingga makin memperkuat dugaan bahwa UUPA adalah produk PKI.

Kedua, dari segi orientasi, kedua undangundang ini sangat berbeda, pada UUPA hakhak rakyat atas tanah sangat ditonjolkan atau dilindungi demi mengangkat perekonomian mereka. Dengan kata lain UUPA sangat populis, dan menurut Moh. Mahfud MD, ${ }^{18}$ berkarakter responsif dan memenuhi tuntutan rasa

${ }^{18}$ Moh. Mahfud MD. 1998. Politik Hukum Di Indonesia. Jakarta: LP3ES. HIm. 347. 
keadilan yang selama ini didambakan oleh masyarakat Indonesia. Dengan hak-hak rakyat yang makin jelas diharapkan akan diangkat derajat mereka baik sosial maupun ekonominya. Sedangkan UUPP berorientasi pada pertumbuhan ekonomi negara, di mana kepentingan negara dalam menggiatkan pembangunan harus diutamakan.

Dengan demikian jelaslah, bahwa alasan pertama adalah untuk mengantisipasi bila suatu saat UUPA diganti, maka UUPP tidak perlu diganti. Tetapi kalau cantolannya UUPA dan UUPA suatu saat diganti maka jelaslah Undang-Undang Pokok Pertambangan (UUPP) juga akan diganti.

Adapun alasan kedua adalah, bila dalam konsideran dicantumkan UUPA sebagai landasan maka jelas akan menghambat tujuan diundangkannya UUPP. Karena UUPA sangat menghormati hak-hak atas tanah seseorang atau badan hukum (populis) sedangkan UUPP cenderung mengabaikan hak-hak rakyat dengan dalih untuk pembangunan.

\section{Simpulan}

Menyimak uraian di atas maka jelaslah adanya pertentangan hukum di mana suatu peraturan perundang-undangan telah mengatur dan memberi tafsiran yang otentik terhadap satu objek di bidang keagrarian (bumi, air, dan ruang angkasa serta kekayaan yang terkandung di dalamnya) diatur pula dalam undang-undang yang lain secara sektoral.

Pengaturan di dalam undang-undang yang bersifat sektoral ini pada kenyataannya berdampak pada masyarakat, yakni mengabaikan hak-hak atas tanah masyarakat dan amat merugikan.
Dengan demikian perlu ditegaskan mana yang menjadi undang-undang pokok sehingga undang-undang yang bersifat sektoral menginduk pada undang-undang pokok tersebut, dan bila terjadi suatu permasalahan dalam masyarakat akan mudah dicari jalan keluarnya.

\section{Daftar Pustaka}

Abrar. 1999. "Sepercik Pemikiran Mengenai Hak Menguasai Negara atas Pertambangan di indonesia." Jurnal Hukum dan Keadilan. Vol. 2. No.1.

Both, Anne dan Peter MacCawley. 1985. "Perekonomian Indonesia Sejak Pertengahan Tahun Empat Puluhan". Dalam Anne Both dan Peter MacCawley. Ekonomi Orde Baru. Jakarta: LP3ES.

Harsono, Boedi. 1997. Hukum Agraria Indonesia: Sejarah Pembentukan UUPA Isi dan Pelaksanaannya. Jilid 1. Edisi Revisi. Jakarta: Djambatan.

Manan, Bagir. 1995. "Aspek Hukum Penguasaan Daerah atas Bahan Galian." Makalah disampaikan dalam Seminar Nasional Pertambangan. Diselenggarakan oleh Lembaga Penelitian Unpad. Bandung.

Mackie, Jamie. 1967. Problems of Indonesian Inflation. Ithaca: Cornell Modern Indonesian Project.

MD, Moh. Mahfud. 1993. "Perkembangan Politik Hukum: Studi Tentang Pengaruh Konfigurasi Politik Terhadap Produk Hukum di Indonesia." Disertasi S3. UGM. 
—. 1998. Politik Hukum di Indonesia. Jakarta: LP3ES.

Parlindungan, A.P. 1991. Komentar Atas Undang-Undang Pokok Agraria. Bandung: Mandar Maju. 1993. "Peninjauan Beberapa Produk Hukum yang Berkaitan dengan UUPA". Pidato Purna Bakti selaku Guru Besar Tetap USU.

1993. Komentar Atas Undang-Undang Penataan Ruang (UU No.24 Tahun 1992). Bandung: Mandar Maju.
Rajagukguk, Erman. 1995. Hukum Agraria, Pola Penguasaan Tanah dan Kebutuhan Hidup. Jakarta:Chandra Pratama.

Salindeho, John.1987. Masalah Tanah dalam Pembangunan. Jakarta: Sinar Grafika.

Sumantoro. 1986. Hukum Ekonomi. Jakarta: Ul Press.

Saripado,Syamsul Bahri Dt. 1987. Hukum Agraria Indonesia Dulu dan Kini. Tanpa Penerbit. 